УДК 911.3:314(571.52)

DOI 10.18101/2587-7148-2020-2-49-57

\title{
КОНЦЕПЦИЯ МОБИЛЬНОГО КАРКАСА РАССЕЛЕНИЯ НАСЕЛЕНИЯ (НА ПРИМЕРЕ РЕСПУБЛИКИ ТЫВА)
}

\section{Ц. Д. Гончиков, Б. О. Гомбоев, М. К. Мандыт}

(C) Гончиков Цыбен Дашицыренович

Кандидат географических наук, доцент

Бурятский государственный университет имени Доржи Банзарова, Россия, 670000, г. Улан-Удэ, ул. Смолина 24a,

E-mail: ek-geo@bsu.ru

\section{(ㄷ Гомбоев Баир Октябрьевич}

Доктор географических наук, заведующий кафедрой географии и геоэкологии, г.н.с. лаборатории геостратегических исследований и пространственного развития ${ }^{1}$ Бурятский государственный университет имени Доржи Банзарова, ${ }^{2}$ ФГБУН «Байкальский институт природопользования» СО РАН Россия, 670000, г. Улан-Удэ, ул. Смолина 24a, E-mail: bgom@binm.bscnet.ru

\section{(C) Мандыт Марта Кан-ооловна}

Ассистент Бурятский государственный университет имени Доржи Банзарова, Россия, 670000, г. Улан-Удэ, ул. Смолина 24a,

E-mail:mandyt88@mail.ru

В статье предлагаются новые понятия «мобильный и стационарный каркасы расселения», дана сравнительная характеристика стационарного и мобильного каркасов расселения, анализированы статистические данные по поголовью домашних животных по экономическим районам и кожуунам Республики Тыва по состоянию 2016 г.

Ключевые слова: каркас расселения, кожууны, кочевые скотоводы, население, охотникиоленеводы, охотники-скотоводы, Республика Тыва, стационарный и мобильный каркасы расселения.

\section{Для цитирования}

Гончиков Ц. Д., Гомбоев Б. О., Мандыт М. К. Концепция мобильного каркаса расселения населения (на примере Республики Тыва) // Вестник Бурятского государственного университета. Биология, география. 2020. № 2. С. 49-57.

\section{Введение}

Республика Тыва один из немногих субъектов РФ с многовековым кочевым укладом жизни и быта населения. Она всего за 75 лет прошла сложный процесс трансформации кочевого образа жизни с сезонным мобильным расселением до агропромышленного комплексного хозяйства с формирующейся системой современных населенных пунктов. Мобильный каркас расселения для республики 
является первичным, традиционным и не менее важным, чем другие элементы расселения. И в настоящее время мобильный каркас расселения является основой сохранения и развития не только животноводческой специализации Тывы в межрегиональном разделении труда, но и этнической культуры и традиции тувинского этноса.

Мобильный каркас расселения характерен для целого ряда зарубежных стран. Наиболее типичная из них Монголия, в составе которой и состояла Тыва в историческом прошлом. Однако специального исследования мобильного каркаса расселения в РФ и зарубежных странах нами не обнаружено. Именно поэтому, впервые в науке предлагаем концепцию мобильного каркаса расселения на примере Республики Тыва.

Мобильный каркас расселения исторически связан с формированием и развитием животноводческого направления в производящем хозяйстве степного и лесостепного населения Монголии и Забайкалья в начале бронзового века в связи с аридизацией климата. Животноводство становится экономической основой развития кочевых народов. Оно развивалось, адаптируясь к местным природно-климатическим условиям в соответствии с широтной зональностью и высотной поясностью. В Тыве, в рельефе которой преобладают горы (до 82\% ее территории), изрезанные ущельями с крутыми склонами, получило развитие многоотраслевое животноводство. На относительно равнинных участках, плоскогорьях и среднегорьях основными видами домашних животных были и остаются овцы, козы и крупный рогатый скот, наиболее приспособленные к степным и лесостепным пастбищам. На более высоких и суровых природно-климатических условиях получило развитие яководство и оленеводство. В качестве транспортного средства, кроме лошадей, использовались верблюды и олени. Характерной чертой кочевого животноводства является сезонное перемещение (миграция) животных в поисках кормовых угодий (пастбищ). Такой способ содержания домашних животных имел определенное экономическое и экологическое значение. В условиях натурального хозяйства животноводство удовлетворяло все основные потребности населения, включая питание и одежду. В дальнейшем, по мере развития торговых связей с другими территориями животноводство становится отраслью специализации хозяйства Тывы. Необходимо особо подчеркнуть, что сезонные кочевки исключают перевыпас скота и способствуют сохранению естественного биоразнообразия и продуктивности кормовых угодий в результате сохранения почвенного покрова. Важно также заметить, что пять видов домашних животных (овцы, козы, крупный рогатый скот, лошади, верблюды) практически не конкурируют между собой на кормовых угодьях: каждый из них съедает «свои» виды трав в соответствии с их физиологическими потребностями и физическими способностями их вырывания (срезания). В качестве летнего пастбища выбирались более высокие и прохладные, открытые пространства 
Ц. Д. Гончиков, Б. О. Гомбоев, М. К. Мандыт Концепция мобильного каркаса расселения населения (на примере Республики Тыва)

среднегорья или северные и северо-западные склоны высокогорий (в связи с западными и северо-западными ветрами). Зимние пастбища устраивались, наоборот, на более теплых южных и юго-восточных склонах гор. Осенние пастбища выбирались с учетом широкого выбора кормовых угодий в период их созревания, весенние с учетом сохранности подножных кормов после суровой зимы. Необходимо заметить, что выбор сезонных пастбищ, грамотное и последовательное использование всей территории пастбищ в зависимости от сочетания различных видов трав и количества (поголовья) скота, не допуская беспорядочного вытаптывания кормовых угодий, синхронизированное во времени с продолжительностью сезонов (в зависимости от погодных условий года) - это своеобразное искусство каждого животноводакочевника, накопленное веками. Таким образом, постепенно формировались устойчивые маршруты (скотопрогонные коридоры) миграций домашних животных и совокупность автономных, рассредоточенных чабанских, пастушеских, коневодческих и оленеводческих стоянок и стойбищ. Протяженность маршрутов зависело от экологической емкости внутренних котловин Тывы, количества скота, степени сокращения пригодной территории в связи с развитием земледелия, разработки природных ресурсов, изъятия земель под строительство населенных пунктов, дорог и т. Д. В историческом аспекте происходило сокращение длины маршрутов сезонных кочевок с сотен километров на десятки. В настоящее время протяженность маршрутов составляет в среднем 35-40 км в зависимости от видов скота. Практически одновременно появился охотничий промысел, получивший наибольшее развитие в зоне тайги. Он был связан не только с круглогодичной охотой на парнокопытных, но и с сезонной добычей пушнины. Охотничий промысел развивался на основе сети временных стоянок. Таким образом, на территории Тывы исторически изначально сформировался мобильный каркас расселения, связанный с отгонно-пастбищным животноводством и охотничьим промыслом, экологически и экономически максимально адаптированных к региональным природно-климатическим условиям. Своеобразными организующими и духовными центрами в сети мобильных поселений в прошлые времена выступали дацаны и центры сбора ясаков и податей, совмещенные с администрацией родовых знатей и торговыми функциями.

Современный каркас расселения региона имеет двухслойную территориальную структуру (Бакланов, 2006), которую можно разделить на стационарную (оседлую) и мобильную. Стационарный каркас расселения не меняет кардинально географическое положение своего ареала, смена возможно в ходе развития: городские и сельские поселения расширяют свои границы или появляются в районах нового освоения, дороги увеличивают свою протяженность. По мере социальноэкономического развития территории (концентрации производства и населения) увеличивается количество городских и сельских стационарных поселений, а также 
протяженность трасс. Современный мобильный каркас расселения также не меняет кардинально географическое положение своего ареала. Например, стоянки, стойбища и скотопрогонные коридоры номадов. Мобильность проявляют только стоянки и стойбища в границах своего ареала, меняя фиксированный набор отмеченных сезонных локаций. Мобильный каркас расселения - совокупность временных, перемещающихся по сезонам года, животноводческих стоянок и стойбищ, а также временных, таежных охотничьих стоянок.

В понятие «каркас» вкладывается смысл сохранения территориальной организации расселения: у оседлых народов в фиксированных локациях с постоянным проживанием в них, а у кочевых в сезонном чередовании фиксированного набора локаций стоянок и стойбищ.

Таблица 1

Сравнительная характеристика стационарного

и мобильного каркасов расселения

\begin{tabular}{|c|c|c|c|}
\hline \multirow[t]{2}{*}{ № } & \multirow[t]{2}{*}{ Признаки } & \multicolumn{2}{|c|}{ Каркас расселения } \\
\hline & & Стационарный каркас & Мобильный каркас \\
\hline 1. & $\begin{array}{l}\text { Элементы } \\
\text { и инфра- } \\
\text { структурное } \\
\text { выражение } \\
\text { каркаса }\end{array}$ & $\begin{array}{c}\text { Линейно-узловой каркас } \\
\text { в инфраструктурном выраже- } \\
\text { нии представлен линейными } \\
\text { элементами: автомобильны- } \\
\text { ми и железными дорогами; } \\
\text { а узловые — населёнными } \\
\text { пунктами. }\end{array}$ & $\begin{array}{c}\text { Линейно-узловой каркас может } \\
\text { быть: без инфраструктурного выра- } \\
\text { жения (система природных ориен- } \\
\text { тиров на местности) или с инфра- } \\
\text { структурным выражением (система } \\
\text { антропогенных ориентиров в виде } \\
\text { ЛЭП или колодцев). Линейные } \\
\text { элементы -скотопрогонные коридо- } \\
\text { ры, а узловые - локации стоянок } \\
\text { и стойбищ. }\end{array}$ \\
\hline 2. & $\begin{array}{c}\text { Современная } \\
\text { стратегия тер- } \\
\text { риториализа- } \\
\text { ции каркаса }\end{array}$ & $\begin{array}{c}\text { Расширение границ ареа- } \\
\text { ла в форме базо-трассовой } \\
\text { стратегии (Космачев, 1974) } \\
\text { освоения территории и усиле- } \\
\text { ния антропогенной нагрузки } \\
\text { на окружающую природную } \\
\text { среду. } \\
\end{array}$ & $\begin{array}{c}\text { Сохранение границ ареала пере- } \\
\text { ключением в его пределах режимов } \\
\text { «присутствия» и «отсутствия» } \\
\text { антропогенной нагрузки на окру- } \\
\text { жающую природную среду. }\end{array}$ \\
\hline 3. & $\begin{array}{c}\text { Образ жизни } \\
\text { как культур- } \\
\text { ная основа } \\
\text { стратегии тер- } \\
\text { риториализа- } \\
\text { ции каркаса }\end{array}$ & $\begin{array}{l}\text { Оседлый образ жизни и стро- } \\
\text { ительство жилища стационар- } \\
\text { ного (капитального) характера. }\end{array}$ & $\begin{array}{c}\text { Кочевой образ жизни и заготовка, } \\
\text { сборка мобильного каркаса юрты } \\
\text { или чума. }\end{array}$ \\
\hline 4. & $\begin{array}{c}\text { Смысловое } \\
\text { выражение } \\
\text { понятия «кар- } \\
\text { кас расселе- } \\
\text { ния» }\end{array}$ & $\begin{array}{c}\text { Каркас с точки зрения про- } \\
\text { странственной организации } \\
\text { процесса освоения территории } \\
\text { (регионального развития) }\end{array}$ & $\begin{array}{c}\text { Каркас с точки зрения сохранения } \\
\text { территориальной организации } \\
\text { традиционного природопользова- } \\
\text { ния этноса, его культуры и образа } \\
\text { жизни. }\end{array}$ \\
\hline
\end{tabular}


Ц. Д. Гончиков, Б. О. Гомбоев, М. К. Мандыт Концепция мобильного каркаса расселения населения (на примере Республики Тыва)

\begin{tabular}{|c|c|c|c|}
\hline 5. & $\begin{array}{c}\text { Природно- } \\
\text { ресурсная } \\
\text { основа образа } \\
\text { жизни }\end{array}$ & $\begin{array}{c}\text { Стационарное природополь- } \\
\text { зование: постоянная доставка } \\
\text { ресурсов к месту житель- } \\
\text { ства населения и местам } \\
\text { его трудоустройства, либо } \\
\text { строительство стационарных } \\
\text { населённых пунктов в местах } \\
\text { природопользования. }\end{array}$ & $\begin{array}{c}\text { Мобильное природопользование: } \\
\text { постоянная миграция населения } \\
\text { к местам воспроизводства ресурсов } \\
\text { и ресурсопользования. }\end{array}$ \\
\hline 6. & $\begin{array}{c}\text { Режим за- } \\
\text { груженности } \\
\text { линейно- } \\
\text { узловых } \\
\text { структур }\end{array}$ & $\begin{array}{c}\text { Постоянно-загруженный ре- } \\
\text { жим всех элементов }\end{array}$ & $\begin{array}{c}\text { Сезонно-загруженный режим } \\
\text { элементов }\end{array}$ \\
\hline 7. & $\begin{array}{c}\text { Положение } \\
\text { каркаса по } \\
\text { отношению } \\
\text { к традицион- } \\
\text { ному приро- } \\
\text { допользова- } \\
\text { нию номадов }\end{array}$ & Внешнее & Внутреннее \\
\hline 8. & $\begin{array}{c}\text { Концентрация } \\
\text { населения }\end{array}$ & Сфокусированная & Расфокусированная \\
\hline
\end{tabular}

Необходимо отметить, что на протяжении ряда веков в Тыве сформировались три основных хозяйственно-культурных типа (ХКТ), характеризующих внутренние территориальные различия сельскохозяйственного освоения региона и сохранившихся до наших дней.

Кочевые скотоводы горно-степной зоны. В конце XIX - начале XX вв. в центральной, западной и южной частях Тывы, где преобладают горно-степные ландшафты (основная часть территории современных Центральной, Западной и Южной экономических районов) жили западные тувинцы, составлявшие около 95\% всего населения региона. Они традиционно занимались пастбищным животноводством, ориентированным на разведение, прежде всего, овец, коз, крупного рогатого скота, а также лошадей и верблюдов с сезонными «вертикальными» кочевками (История Тувы, 2014). Их хозяйство дополнялось у значительной части населения орошаемым земледелием, охотой, собирательством и рыболовством. У кочевников, живших в решетчатых войлочных юртах, насчитывалось более 12000 хозяйств, составивших основу мобильного расселения.

Охотники-оленеводы горно-таежной зоны. Бассейны верхних течений рек Бий-Хем и Каа-Хем, представляющих основную часть современного Восточного экономического района, населяли восточные тувинцы (тувинцы-тоджинцы), занимавшиеся охотой и оленеводством. У них, составлявших всего $3 \%$ коренного населения Тувы, насчитывалось около 400 хозяйств, связанных с охотничьим 
промыслом (мясо, пушнина) и кочевым оленеводством с круглогодичными «вертикальными» кочевками. Оленеводство было, прежде всего, вьючноверхового типа с доением. В структуре этнического хозяйства важное значение имело также сезонное собирательство и рыболовство. В качестве мобильного жилища использовали, в отличие от западных тувинцев, чум, который летом крыли выделенной берестой, а в холодное время - обработанными шкурами.

Кочевые и полукочевые охотники-скотоводы как переходный хозяйственнокультурный тип. На стыке между горными степными и таежными зонами, на среднем течении рек Бий-Хем и Каа-Хем (сумоны Кол и Белбей) заселялись всего 2\% коренного населения региона. Здесь насчитывалось около 250 хозяйств. В отличие от предыдущих типов, ведущие отрасли хозяйства - охота и скотоводство имели равное значение и могли колебаться в ту или иную сторону в зависимости от погодных условий года. Важную роль в хозяйстве играло собирательство по сравнению с рыболовством. В качестве жилища использовали также чум, крытый в течение всего года (в отличие от тоджинцев) берестой или кусками коры лиственницы. Небольшая часть охотников-скотоводов вела полукочевой образ жизни, связанный с постоянными срубными, нередко юртообразными, домами на зимниках.

Тыва, как было отмечено, исторически овцеводческий регион. В настоящее время количество овец и коз приближается в 1200000 голов, что составляет абсолютное большинство $(83,6 \%)$ в общем поголовье скота республики. Особенно высокие темпы роста поголовья овец были в 1951-1971 гг. (4,1 раза), когда количество овец достигло 967,1 тыс. гол. Доля крупного рогатого скота в общей численности домашних животных составляет всего $11,5 \%$, лошадей - 4,8\%, оленей и верблюдов соответственно, $0,1 \%$ и $0,01 \%$.

Наибольшее количество домашних животных размещено в Западном и Центральном экономических районах: овец и коз - 83,3\%, крупного рогатого скота - 79,6\%, лошадей - 77,4\% (табл. 2). Соответственно, большее количество животноводческих мобильных стоянок горно-степной зоны приходится на 2 отмеченных района. В остальных районах, особенно в горно-таежном Восточном показатели заметно меньше.

В 2017 г. появились 220 новых чабанских стоянок, что свидетельствует о дальнейшем развитии овцеводства в рыночных условиях и большой роли мобильного каркаса расселения в экономике региона.

Таблица 2

Поголовье домашних животных по экономическим районам, кожуунам РТ по состоянию 2016 г. (в хозяйствах всех категорий; голов, \%)

\begin{tabular}{|c|c|c|c|c|c|c|}
\hline \multirow{2}{*}{$\begin{array}{c}\text { Экономические районы, } \\
\text { кожууны }\end{array}$} & \multicolumn{2}{|c|}{ MPC } & \multicolumn{2}{|c|}{ КРС } & \multicolumn{2}{|c|}{ Лошади } \\
\hline & 1178375 & $\%$ & голов & $\%$ & голов & $\%$ \\
\hline Всего по республике & 248023 & 100 & 161800 & 100 & 68079 & 100 \\
\hline
\end{tabular}


Ц. Д. Гончиков, Б. О. Гомбоев, М. К. Мандыт Концепция мобильного каркаса расселения населения (на примере Республики Тыва)

\begin{tabular}{|c|c|c|c|c|c|c|}
\hline $\begin{array}{l}\text { Центральный } \\
\text { экономический район }\end{array}$ & 3749 & 21,0 & 51608 & 31,9 & 24568 & 36,1 \\
\hline т.ч.г. Кызыл & 108739 & 1,5 & 1020 & 2,0 & 37 & 0,1 \\
\hline Кызылский кожуун & 25756 & 43,8 & 15909 & 30,8 & 9840 & 40,0 \\
\hline Пий-Хемский & 24234 & 10,4 & 8237 & 16,0 & 4515 & 18,4 \\
\hline Тандинский & 53081 & 9,8 & 9415 & 18,2 & 3244 & 13,2 \\
\hline Улуг-Хемский & 32464 & 21,4 & 11006 & 21,3 & 3952 & 16,1 \\
\hline Чеди-Хольский & 733619 & 13,1 & 6021 & 11,7 & 2980 & 12,2 \\
\hline $\begin{array}{l}\text { Западный экономический } \\
\text { район }\end{array}$ & 2121 & 62,3 & 77198 & 47,7 & 28155 & 41,3 \\
\hline т. ч.г. Ак-Довурак & 117121 & 0,3 & 609 & 0,8 & 35 & 0,1 \\
\hline Бай-Тайгинский & 111988 & 16,0 & 12034 & 15,6 & 3121 & 11,1 \\
\hline Барун-Хемчикский & 107123 & 15,3 & 14734 & 19,1 & 7108 & 25,2 \\
\hline Дзун-Хемчикский & 69181 & 14,6 & 16025 & 20,7 & 6558 & 23,3 \\
\hline Монгун-Тайгинский & 139708 & 9,4 & 9970 & 12,9 & 1025 & 3,6 \\
\hline Овюрский & 157025 & 19,0 & 9658 & 12,5 & 5053 & 17,9 \\
\hline Сут-Хольский & 29352 & 21,4 & 8512 & 11,0 & 4028 & 14,3 \\
\hline Чаа-Хольский & 18973 & 4,0 & 5656 & 7,3 & 1227 & 4,4 \\
\hline $\begin{array}{l}\text { Восточный } \\
\text { экономический район }\end{array}$ & 563 & 1,6 & 9167 & 5,7 & 3254 & 4,8 \\
\hline т. ч. Тоджинский & 18410 & 3,0 & 2405 & 26,2 & 355 & 10,9 \\
\hline Каа-Хемский & 177760 & 97,0 & 6762 & 73,8 & 2899 & 89,1 \\
\hline $\begin{array}{l}\text { Южный экономический } \\
\text { район }\end{array}$ & 3248 & 15,1 & 23827 & 14,7 & 12102 & 17,8 \\
\hline т. ч. Тере-Хольский & 58746 & 1,8 & 3812 & 16,0 & 1547 & 12,8 \\
\hline Тес-Хемский & 115766 & 33,0 & 7923 & 33,3 & 4240 & 35,0 \\
\hline Эрзинский & & 65,2 & 12092 & 50,7 & 6315 & 52,2 \\
\hline
\end{tabular}

По сочетанию стационарного и мобильного каркасов расселения экономические районы республики существенно различаются. Западный горнопромышленный район с многоотраслевым сельским хозяйством (овцеводство на горных пастбищах, мясное скотоводство, охотничий промысел, очаги земледелия) отличается наиболее развитой сетью мобильных животноводческих стоянок $(50,4 \%)$. Особенно выделяются Овюрский и Сут-Хольский кожууны. Центральный индустриальный район со специализацией на перерабатывающей промышленности, с горнорудным производством и развитым мясо-шерстным животноводством и орошаемым земледелием концентрирует более $1 / 4$ (29,7\%) мобильных сельских стоянок региона. Здесь выделяется Кызылский кожуун. Доля Южного туристско-рекреационного района с многоотраслевым сельским хозяйством в общей сети стоянок составляет $15,8 \%$, Восточного экономически слаборазвитого сельскохозяйственного района 
со специализацией на охотничьем промысле, оленеводстве, с очагами мясного животноводства, овцеводстве на горных пастбищах и земледелии - 4,1\%. В данных районах относительно развитой сетью мобильных поселений выделяются Эрзинский, Тес-Хемский и Каа-Хемский кожууны.

Сочетание стационарного и мобильного каркасов расселения по экономическим районам, соответственно, составляет $34,0: 50,4 ; 38,0: 29,7 ; 12,0: 15,8$ и 16,0: 4,1\%. Они раскрывают уровень развития сети стационарных (оседлых) и мобильных поселений, отражающих характер промышленного и сельскохозяйственного освоения территорий экономических районов региона. Как видим, в Западном и Южном экономических районах, за исключением хорошо развитого Центрального и слабо освоенного, экстремального по природно-климатическим условиям Восточного, преобладают мобильное расселение над стационарными.

Таким образом, исторически прослеживается основная ось «запад восток» в развитии мобильного каркаса расселения в соответствии с природноклиматическими условиями, особенностями заселения и освоения территории региона. Необходимо подчеркнуть, что стационарные и мобильные каркасы расселения, имея целый ряд различий, не только уживаются, они развиваются, дополняя друг друга. Стационарный каркас расселения обеспечивает мобильный всем необходимым, прежде всего, в социальной сфере и придает последнему, как носителю традиционного образа жизни и быта населения, устойчивость в развитии этнического природопользования и воспроизводства населения не только на центральных хорошо освоенных территориях (кожуунах), но и на дальних, окраинных частях республики. Мобильный каркас расселения, в свою очередь, является основой сохранения и развития агропромышленного комплекса республики в межрайонном разделении труда, а также этнической культуры и традиции тувинцев.

\section{Литература}

1. Бакланов П. Я. Территориальные структуры хозяйства в современном региональном управлении // Региональные исследования.-2006. — № 2 (8). - c. 3-8.

2. История Сибири с древнейших времен до наших дней: в 5 томах. Т. 1. Древняя Сибирь.- Ленинград: изд-во «Наука», ленинградское отд-ние, 1968. - 372 с.

3. История Тувы: В 2 т.- T.I.-2-е изд. перераб. и доп. / Под общ. ред. С. И. Вайнштейна, М. Х. Маннай-оола.— Кызыл: ОАО «Тываполиграф», 2014.-368 с.

4. Космачев К. П. Пионерное освоение тайги: (экономико-географические проблемы) / Отв. ред. акад. В. Б. Сочавы.- Новосибирск: Наука Сиб. отд-ние, 1974. — 144 с.

5. Краткий юбилейный статистический сборник к 100-летию единения России и Тувы: Стат. сборник / Тывастат.-Кызыл, 2014-208 с.

6. Мангатаева Д. Д. Система расселения населения: региональный аспект.-Новосибирск: Наука, Сиб. отд-ние, 1988.-80 с.

7. Мандыт М. К. Историко-географические особенности формирования тувинского народа // Вестник Бурятского государственного университета.-2015.—- Вып. 4.- С. 253-257. 
Ц. Д. Гончиков, Б. О. Гомбоев, М. К. Мандыт Концепция мобильного каркаса расселения населения (на примере Республики Тыва)

8. Народное хозяйство Тувинской АССР: стат. сб. / ЦСУ РСФСР. Стат. упр. Тувин. АССР / сост., ред. В. И. Качаев.- Кызыл, Тув. кн. изд-во, 1971.-307 с.

9. Статистический ежегодник Республики Тыва: Стат. сб. / Тывастат.-Кызыл, 2016. $241 \mathrm{c}$.

10. Стратегия пространственного развития Российской Федерации на период 2025 года: Распоряжение Правительства Российской Федерации от 13.02.2019 г. № 207-р. 2019._- 116 с.

\section{THE CONCEPT OF THE MOBILE FRAME OF THE RESETTLEMENT OF THE POPULATION (ON THE EXAMPLE OF THE REPUBLIC OF TUVA)}

T. D. Gonchikov, B. O. Gomboev, M. K. Mandyt

Gonchikov Tsyben D.

Ph.D. (Geography), Associate Professor

D. Banzarov Buryat State University,

Russia, 670000, Ulan-Ude, 24 «a» Smolina st.,

E-mail: ek-geo@bsu.ru

Gomboev Bair $O$.

Doctor of Geography, Professor

Head of the Department of Geography and Geoecology,

${ }^{1}$ D. Banzarov Buryat State University

${ }^{2}$ Chief researcher of the Baikal Institute of Nature Management SB RAS,

Russia, 670000, Ulan-Ude, 24 «a» Smolina st.,

E-mail: bgom@binm.bscnet.ru

Mandyt Marta K.

Assistant

D. Banzarov Buryat State University,

Russia, 670000, Ulan-Ude, 24 «a» Smolina st.,

E-mail: mandyt88@mail.ru

The article offers new concepts of «mobile and stationary settlement frames», gives a comparative characteristic of stationary and mobile settlement frames, analyzes statistical data on the number of domestic animals in the economic regions and municipalities of the Republic of Tuva as of 2016.

Keywords: settlement framework, municipalities, nomadic pastoralists, population, reindeer herders, hunters-pastoralists, Republic of Tuva, stationary and mobile settlement frameworks. 